\title{
Evaluation of CANWET model for hydrologic simulations for upper Canagagigue Creek watershed in southern Ontario
}

\author{
A. Singh ${ }^{1}$, R.P. Rudra ${ }^{2 *}$ and B. Gharabaghi ${ }^{2}$ \\ ${ }^{I}$ Credit Valley Conservation Authority, 1255 Old Derry Rd., Mississauga, ON, L5N 6R4 Canada; and \\ ${ }^{2}$ School of Engineering, University of Guelph, Guelph, ON, N1G 2W1, Canada. \\ *Email: rrudra@uoguelph.ca
}

Singh, A., R. P. Rudra, and B. Gharabaghi. 2012. Evaluation of CANWET model for hydrologic simulations for upper Canagagigue Creek watershed in southern Ontario. Canadian Biosystems Engineering/Le génie des biosystèmes au Canada 54:1.7-1.18. This paper discusses the uncertainty associated with the dominant hydrologic processes for watershed-scale water budget calculations in a rural southern Ontario watershed. Very little field data is available that would help in direct calculation of spatial and temporal variation of some of the key components of the water budget, including evapotranspiration and groundwater recharge on a watershed scale. Therefore, the Ontario Ministry of the Environment has recommended the use of a suite of hydrologic models for water budget calculations. The methodologies behind these models vary in procedural complexities and spatial and temporal resolutions. In the current study CANWET (Canadian Nutrient and Water Evaluation Tool) model, which uses relatively simplified approach as compare to other physically based models, was evaluated for water balance studies in southern Ontario. The model was applied to the Upper Canagagigue Creek watershed of the Grand River basin. The model was run for a ten-year period (April 1990 March 2000) and outputs from the hydrologic simulations were used to analyze streamflow hydrographs and water budget components on annual, seasonal, monthly, and daily time frames. The model partitioned the annual water budget into $60 \%$ evapotranspiration, $12 \%$ surface runoff, and $28 \%$ sub-surface flow. These values are supported by the long-term annual observed data and by literature. The analysis of water balances on seasonal and monthly basis revealed that the snowmelt component of the model, which is critical for winter and spring hydrology, requires improvement. The snowmelt equation used in the model is simplified degree-day equation. This study shows that in the Canagagigue Creek watershed, more than $90 \%$ of precipitation in summer months is lost to evapotranspiration and more than half of precipitations in the winter/spring months recharge groundwater. The CANWET model was found to be a useful tool in calculation of watershed-scale water budget components reasonably well on annual $\left(R^{2}=0.89\right)$, seasonal $\left(R^{2}=0.68\right)$, and monthly $\left(R^{2}=0.68\right)$ time frames. Keywords: CANWET, watershed modeling, source water protection, water budget.

Cet article examine l'incertitude associée avec les processus hydrologiques dominants dans l'évaluations de bilan hydrique à l'échelle d'un bassin versant, dans ce cas-ci dans un bassin d'une région rurale du sud de l'Ontario. Il y a très peu de données empiriques disponibles, résultant de mesures effectuées sur le terrain, qui pourraient aider au calcul direct de variations spatiales et temporelles de quelques éléments clés liés au bilan hydrique, tels l'évapotranspiration et la recharge des nappes phréatiques à l'échelle du bassin versant. Par conséquent, le Ministère de l'environnement de l'Ontario a recommandé l'usage d'un ensemble de modèles hydrologiques pour calculer le bilan hydrique. Les méthodologies propres à ces modèles varient en complexités procédurales et en résolutions spatiales et temporelles. Pour l'étude courante, le modèle CANWET (Canadian Nutrient and Water Evaluation Tool), qui emploie une approche plutôt simplifiée comparativement à d'autres modèles physiques, a été évalué pour des études de bilan en eau dans le sud de l'Ontario. Ce modèle a été appliqué au bassin versant de Upper Canagagigue Creek, situé dans le bassin Grand River. Une période de dix ans (avril 1990 - mars 2000) a été utilisée pour réaliser les simulations avec le modèle et les résultats des simulations hydrologiques ont été utilisés afin d'analyser les hydrogrammes de débit et les composantes du bilan hydrique par intervalles annuelles, saisonnières, mensuelles et quotidiennes. Le modèle a séparé le bilan en eau annuel en $60 \%$ d'évapotranspiration, $12 \%$ de ruissellement de surface, et $28 \%$ d'infiltrations. Ces résultats sont appuyés par les données annuelles observées à long terme et les recherches publiées. L'analyse des bilans d'eau sur des intervalles saisonnières et mensuelles a révélé que la composante du modèle évaluant la fonte de la neige, critique à l'hydrologie hivernale et printanière, nécessite quelques améliorations. L'équation de la fonte des neiges employée dans le modèle est une équation simplifiée de degrés/jour. Cette étude démontre que, dans le bassin versant de Canagagigue Creek, plus de $90 \%$ des précipitations lors des mois estivaux sont perdues par évapotranspiration, et plus de la moitié des précipitations lors des mois hivernaux et printaniers rechargent la nappe phréatique. Le modèle CANWET a été déterminé comme étant un atout raisonnablement utile dans le calcul de bilan hydrique à l'échelle de bassin versant sur des intervalles annuelles $\left(R^{2}=0,89\right)$, saisonnières $\left(R^{2}=0,68\right)$, et mensuelles $\left(\mathrm{R}^{2}=0,68\right)$. Mots-clés: CANWET, Modélisation de bassin versant, protection des sources d'eau, bilan hydrique.

\section{INTRODUCTION}

The Clean Water Act was passed by the Ontario Ministry of Environment (MOE) and received royal assent in 2006 (MOE 2006a). The Act focuses on the assessment of two hydrologic systems: the surface water system and the groundwater system. For the initial steps of any hydrologic evaluation done under the Act, the MOE has described the components of the water budget that play a key role in source-water protection, and suggested a watershed-based approach for appraising these components (MOE 2006b). Surface water budgeting demands quantification of the 
components of the surface water system: evapotranspiration, surface runoff, infiltration, interflow, baseflow, and deep percolation. This may be accomplished using conceptual or numerical modeling. Such water budget evaluations help in the hydrological characterization of a given watershed and in the accounting of the movement of water over time. Further, the MOE plans to use the water budget approach to set quantitative hydrological targets in relation to established targets. It is hoped that this will help to establish long-term water supply strategies, help evaluate the cumulative effects of land and water use, and provide a sub-watershed scale framework for site-scale studies. It will also help to aid in the design of environmental monitoring program, set targets for water conservation, identify data and knowledge gaps, and investigate the possible effects of climate change on water supplies (MOE 2006b).

Conservation authorities and other government agencies are working on assessing the water budgets of watersheds under their jurisdiction. A variety of tools are being investigated for quantifying elements of both surface and groundwater systems, both individually and collectively. Ontario Ministry of Environment guidelines suggest a number of watershed modeling tools, based upon their perceived suitability to the geographic area of application. Such models vary greatly in terms of algorithm complexity, spatial and temporal discretization, and level of interactions between water reservoirs. Typically, surface-water hydrologic models are either infiltration or surface runoff based. Models like GAWSER (Guelph All-Weather Sequential-Events Runoff Model; Schroeter 1996) and HSPF (Hydrologic Simulation Program - FORTRAN; Bicknell et al. 2001) follow an infiltration approach, using the Green and Ampt procedure and an infiltration index solution, respectively. Models like CANWET (Canadian Nutrient and Water Evaluation Tool; Greenland 2004) and SWAT (Soil Water Assessment Tool; Arnold et al. 1998) follow a surface runoff approach, employing the Soil Conservation Services - Curve Number method. These modeling approaches have been widely applied to watersheds all over the world (e.g. Singh et al. 2005; Van Liew et al. 2003). However, the literature on streamflow and water budget characterization, as required under the Clean Water Act of Ontario using models like CANWET, is not available.

This study focused on applying a hydrologic model approach to southern Ontario conditions so as to characterize streamflow and water budget components of concern under the Clean Water Act. The specific objectives of the study were to evaluate the CANWET model that uses relatively simplified hydrologic simulation procedure for the estimation of surface water budget components and streamflow on annual, seasonal, monthly, and daily time frames, and to identify strengths and weaknesses of the model.

\section{MATERIALS AND METHODS}

The CANWET model was selected to meet the water budget objectives of source water protection. The model was applied to the upper portion of the Canagagigue Creek watershed upstream of the Floradale reservoir in the Grand River basin in southern Ontario, Canada (Fig. 1). The surface water simulation procedure in the model is distributed in the sense that it allows for multiple land use/cover scenarios, but each area is assumed to be homogenous with regard to the various attributes considered by the model. A brief description of hydrologic simulation approaches used in CANWET is presented below.

\section{Canadian nutrient and water evaluation tool (CANWET)}

CANWET (Greenland 2004), a GIS-based model, is a Canadian adaptation of the GWLF (Generalized Watershed Loading Function) model developed by Haith and Shoenaker (1987) and Haith et al. (1992). CANWET may be seen as a simplified version of HSPF (Haith, Professor, Cornell University, personal communication) that uses limited parameters and a land-use based approach for hydrologic simulation. In this model the land-use features are classified into three main categories; rural, bare, and urban, which could be sub-classified into a maximum of eight, two, and two types, respectively. The CANWET model provides a continuous streamflow simulation using daily weather data and water balance calculations. It uses the Soil Conservation Services (SCS) curve number (CN) approach (USDA-SCS 1972) for surface runoff generation, and a single-tank approach for sub-surface hydrology.

Streamflow in CANWET consists of the lumped watershed surface-runoff from all source areas plus the baseflow from a shallow saturated zone. Soil moisture is divided into three zones: unsaturated, shallow saturated and deep saturated. The daily water balances for the unsaturated and shallow-saturated zones are computed as:

$$
\begin{aligned}
& \mathrm{U}_{\mathrm{t}+1}=\mathrm{U}_{\mathrm{t}}+\mathrm{R}_{\mathrm{t}}+\mathrm{M}_{\mathrm{t}}-\mathrm{Q}_{\mathrm{t}}-\mathrm{E}_{\mathrm{t}}-\mathrm{PC}_{\mathrm{t}} \\
& \mathrm{S}_{\mathrm{t}+1}=\mathrm{S}_{\mathrm{t}}+\mathrm{PC}_{\mathrm{t}}-\mathrm{G}_{\mathrm{t}}-\mathrm{D}_{\mathrm{t}}
\end{aligned}
$$

where $U_{t}$ and $S t$ are the unsaturated and shallow saturated zone soil moistures at the beginning of day $t$ and $Q_{t}, E_{t}$, $\mathrm{PC}_{t}, \mathrm{G}_{\mathrm{t}}$, and $\mathrm{D}_{\mathrm{t}}$ are surface runoff, evapotranspiration, percolation into shallow saturated zone, groundwater discharge to the stream and seepage flow to the deep saturated zone, respectively, on the day t. The monthly, seasonal and annual estimations were calculated from daily water balance.

Percolation occurs when unsaturated zone water exceeds the maximum soil water capacity of the zone. The potential evapotranspiration is calculated by the Hamon (1961) method and is limited by the available moisture in the unsaturated zone. The shallow unsaturated zone is modeled as a linear reservoir whereas groundwater discharge and deep seepage in CANWET are calculated as:

$$
\begin{aligned}
& \mathrm{G}_{\mathrm{t}}=\mathrm{rS}_{\mathrm{t}} \\
& \mathrm{D}_{\mathrm{t}}=\mathrm{s} \mathrm{S}_{\mathrm{t}}
\end{aligned}
$$

where $\mathrm{r}$ and $\mathrm{s}$ are groundwater recession and seepage 


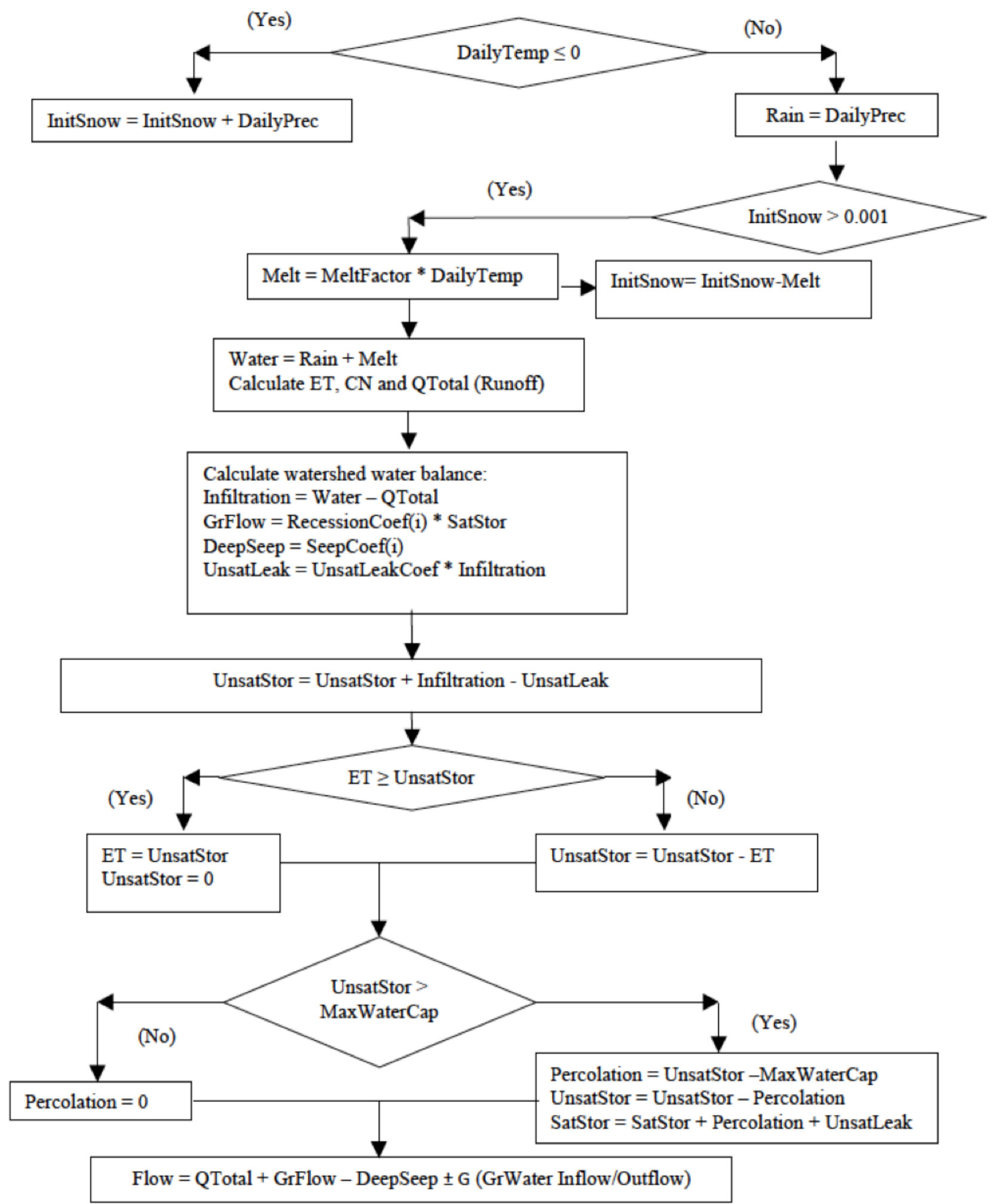

Fig. 1. Flow Chart of CANWET model 


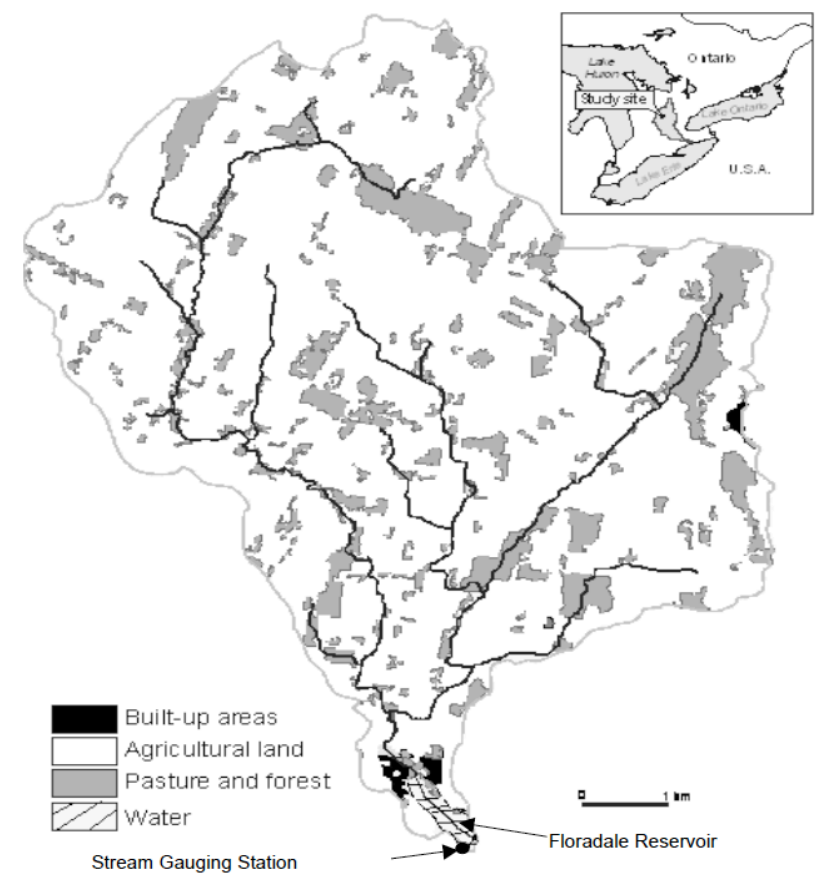

Fig. 2. Location and land use of Upper Canagagigue Creek watershed

constants, respectively, $\mathrm{S}_{\mathrm{t}}$ is the saturation storage $(\mathrm{mm})$, $\mathrm{G}_{\mathrm{t}}$ is groundwater discharge $(\mathrm{mm})$, and $\mathrm{D}_{\mathrm{t}}$ is deep seepage (mm).

In this study the most recent version of the model, CANWET 3.0 (Greenland 2007) was used. This version provides an option to adjust the $\mathrm{CN}$ value, evapotranspiration coefficient, recession coefficient, and seepage coefficient on a monthly basis. The current version may be run for a single basin or aggregated basin; however, spatial flow routing is not yet available. Although GWLF has been widely used for hydrology and non-point source pollution (ShuKuang et al. 2006; Benham et al. 2005), a limited number of studies have been reported on the application of CANWET in Canada (Singh et al. 2007; Boston et al. 2006a, 2006b; Watts et al. 2005). A flow chart that illustrates how the CANWET model works is presented in Fig. 1.

\section{Description of the study area}

The watershed selected for the study was a portion of the Canagagigue Creek watershed upstream of the Floradale reservoir, located between $43^{\circ} 36^{\prime} \mathrm{N}$ and $43^{\circ} 42^{\prime} \mathrm{N}$ latitude, and between $80^{\circ} 33^{\prime} \mathrm{W}$ and $80^{\circ} 38^{\prime} \mathrm{W}$ longitude (Fig. 2). The Canagagigue Creek watershed is a small subwatershed of the Grand River basin in southern Ontario, Canada. The Grand River drains about $7000 \mathrm{~km}^{2}$ into Lake Erie; and the upper Canagagigue Creek watershed drains approximately $53 \mathrm{~km}^{2}$ (5,262 hectares), of which $79.4 \%$ is under agricultural land use, $11.3 \%$ forest and wetlands, $9 \%$ pasture, $0.2 \%$ built up, and $0.1 \%$ open water. Elevations in the watershed range from 362 to $470 \mathrm{~m}$ above the mean sea level and $97 \%$ of the area has a slope of less than $5 \%$. Soils in the watershed belong to the Guelph, Harriston, Dumfries, Burford, and Waterloo series, and are broadly categorized as silts and silt loams.

\section{Model setup}

The model was set up to perform hydrologic simulations for the ten-year period from April 1990 to March 2000, covering a range of normal, dry, and wet years. Delineation and discretization of the Canagagigue Creek watershed into sub-basins was performed using the EPABASINS automatic delineation tool (USEPA 2001). The three GIS layers; the 10-m resolution digital elevation model (DEM), the land use grid layer, and the soils grid layer, were obtained from the Grand River Conservation Authority (GRCA). The upper Canagagigue Creek watershed was defined by the GRCA stream gauging station located upstream of the Floradale reservoir and downstream of the confluence of the two tributaries that drain the eastern and western portions of the watershed. A 100-ha threshold area was used for stream definition. Land uses were sub-classified into cropland (4195 ha), hay/pasture (413 ha), forest (578 ha), and urban (9 ha).

The GIS interface of the CANWET model extracts key modeling parameters from the GIS input layers (land use, soil, and digital elevation layers). The default extracted-values for such parameters were used for evaluating the model. However, the adjustment factors associated with these parameters were calibrated to mimic the temporal variability in the parameters for the study watershed. The curve number $(\mathrm{CN})$ is in general, a key parameter associated with runoff estimation. The $\mathrm{CN}$ values of $75,63,34$, and 80 for cropland, hay/pasture, forest, and urban land, respectively, were extracted by the ArcView interface. CANWET provides an option for monthly adjustment of $\mathrm{CN}$ values to accommodate seasonal variations in hydrology. For example, frozen soil conditions prevalent during winter season and freeze-thaw cycles common during spring season tend to reflect very poorly drained conditions, resulting in significant runoff. On the other hand, the drained and dried soil profiles that occur during the summer and early fall periods tend to increase infiltration and produce little or no surface runoff. Attempts have been made to represent these conditions in various hydrologic model applications using an infiltration approach by temporally varying hydraulic conductivity values (Schroeter 1996; Al-Abed and Whiteley 2002). A similar approach was incorporated in the CANWET model in this study. The monthly $\mathrm{CN}$ adjustment factors given in Table 1 were used to represent monthly changes in $\mathrm{CN}$ values. However, it may be noted here that CANWET does not consider dynamic changes in landuse over the simulation period. Therefore, $\mathrm{CN}$ numbers cannot be changed annually.

The groundwater recession coefficient used to estimate the baseflow contribution to streamflow was adjusted temporally. The monthly-adjusted recession coefficient values used in the present study are also shown 


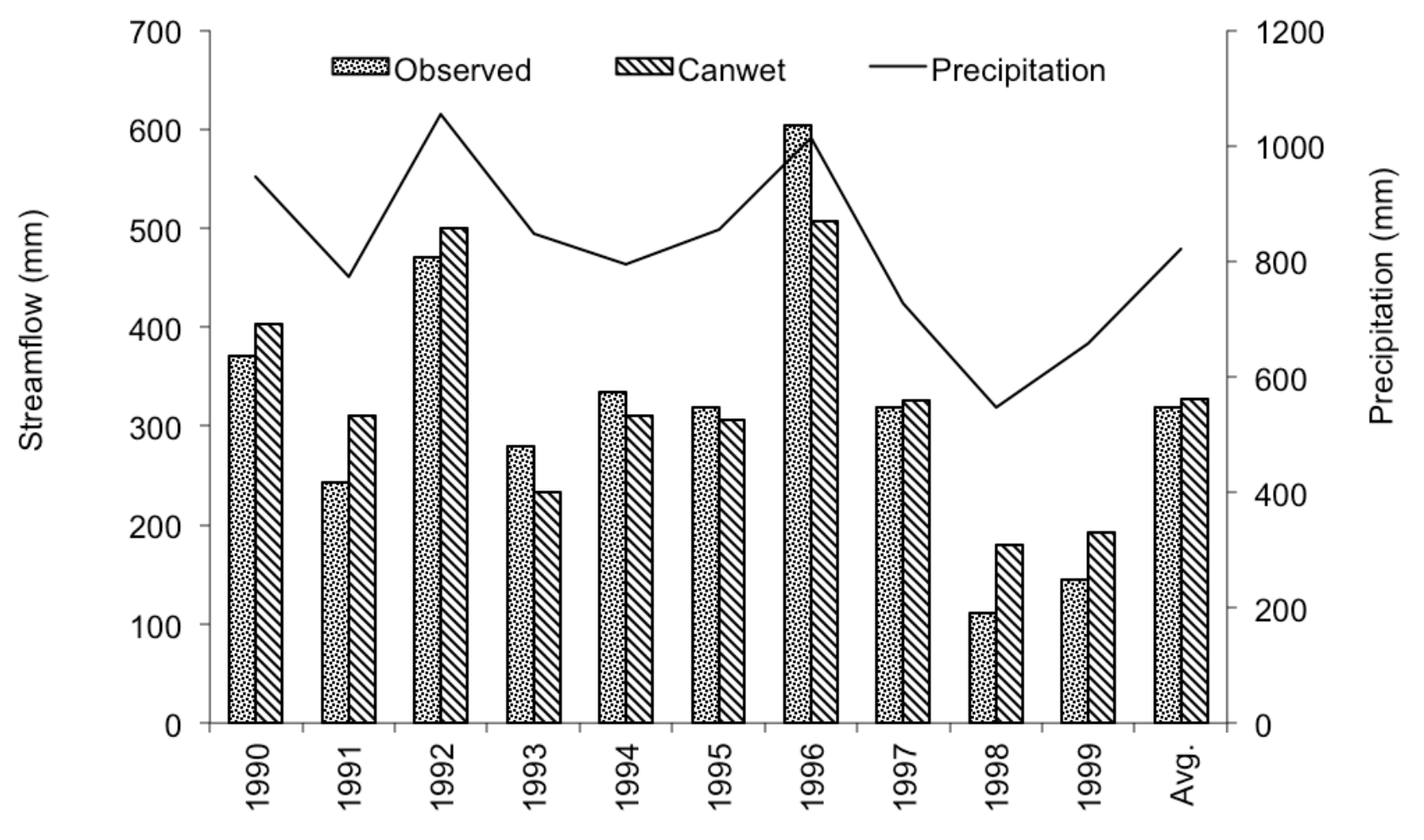

Fig. 3. Comparison of observed and CANWET simulated annual streamflow from 1990-1999.

in Table 1. The model provides an option to vary the groundwater seepage coefficient to account for the possible water movement to, or from, deep aquifers. In this study, monthly values of groundwater seepage were set to zero for all months other than November and December;

Table 1. Temporal variation of adjustment factors after model calibration

\begin{tabular}{lccc}
\hline \multirow{2}{*}{ Month } & \multicolumn{3}{c}{ Adjustment Factors } \\
\cline { 2 - 4 } & ET & CN & $\begin{array}{c}\text { GW } \\
\text { Recession }\end{array}$ \\
\hline April & 1.0 & 1.09 & 0.04 \\
May & 1.0 & 0.9 & 0.01 \\
June & 1.4 & 0.8 & 0.01 \\
July & 1.4 & 0.8 & 0.01 \\
August & 1.4 & 0.8 & 0.01 \\
September & 1.4 & 0.8 & 0.02 \\
October & 1.1 & 0.85 & 0.03 \\
November & 1.0 & 1.05 & 0.04 \\
December & 1.0 & 1.08 & 0.04 \\
January & 1.0 & 1.08 & 0.04 \\
February & 1.0 & 1.08 & 0.04 \\
March & 1.0 & 1.08 & 0.04 \\
\hline
\end{tabular}

ET = Evapotranspiration

$\mathrm{CN}=$ Curve Number

GW Recession $=$ Ground Water Recession and for these two months negative (net seepage into the watershed) values $(-3 \mathrm{~mm} / \mathrm{month})$ were used. The potential evapotranspiration was simulated using the Hamon method (Hamon 1961). The actual evapotranspiration (ET) was estimated using ET adjustment factors (Table 1) to represent the temporal change in cropping conditions of the watershed.

Based upon the soil characteristics of the watershed, the maximum unsaturated water capacity was estimated to be $100 \mathrm{~mm}$. The initial unsaturated storage was considered to be in a saturated condition and set to $100 \mathrm{~mm}$ because the simulation starting time was April 1. At this time of the year there may be some melting snow and soil conditions are close to field capacity. The initial saturated storage was set to $30 \mathrm{~mm}$.

\section{Model evaluation}

The CANWET output was evaluated for the water budget components and streamflow on annual, seasonal, monthly, and daily time frame. The four seasons were defined as; winter (December, January, and February), spring (MarchApril), summer (May-September), and fall (October and November). Evaluations of model performance were conducted both statistically and graphically. Nash-Sutcliffe efficiency coefficients (Nash-E) (Nash and Sutcliffe 1970) and coefficients of determination $\left(\mathrm{R}^{2}\right)$ were used to evaluate the goodness of fit between simulated and 


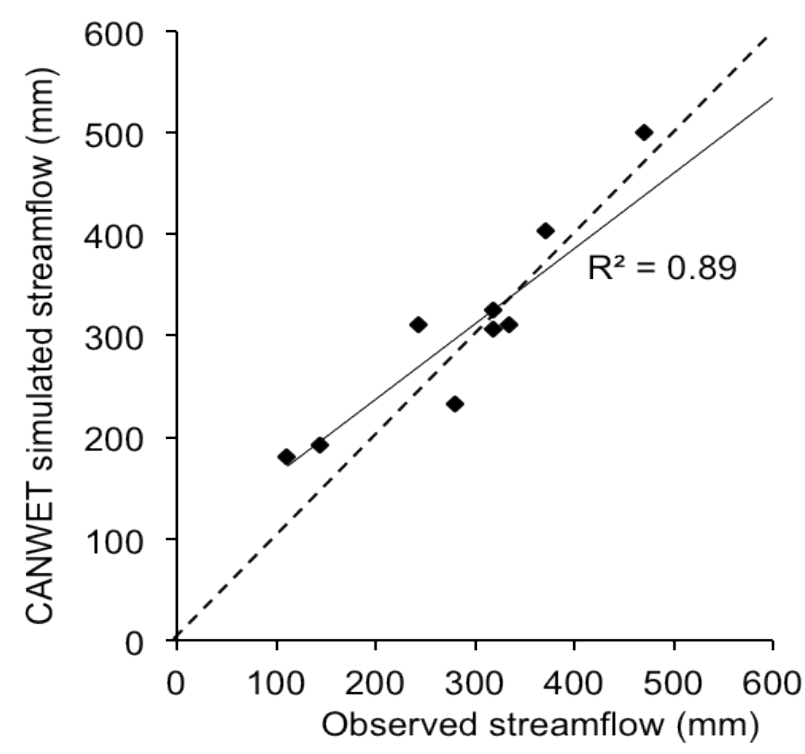

Fig. 4. Scattered Plot for annual observed and CANWET simulated streamflow from 19901999.

observed responses. The annual results were analyzed using a percent simulation error. A probability-ofexceedance analysis (Chin 2000) was used to evaluate how well CANWET simulated the observed range of flows. Finally, scatter diagrams were used to compare simulated and observed responses.

$$
\begin{aligned}
& \text { Nash } E=1-\frac{\sum_{t=1}^{T}\left(Q_{o}^{t}-Q_{m}^{t}\right)^{2}}{\sum_{t=1}^{T}\left(Q_{o}^{t}-\overline{Q_{o}}\right)^{2}} \\
& R^{2}=\frac{n \sum Q_{o} Q_{m}-\left(\sum Q_{o}\right)\left(\sum Q_{m}\right)}{\sqrt{\sqrt{n\left(\sum Q_{o}^{2}\right)-\left(\sum Q_{o}\right)^{2}} / \sqrt{n\left(\sum Q_{m}^{2}\right)-\left(\sum Q_{m}\right)^{2}}}}
\end{aligned}
$$

where $Q_{o}$ is observed stream flow, $Q_{m}$ is modeled stream flow, $\mathrm{t}$ is time step varying from 1 to total simulation time $\mathrm{T}$ and $\mathrm{n}$ is number of time steps.

\section{RESULTS AND DISCUSSION}

The analysis of simulated and observed streamflow and water budget quantities were conducted on annual,
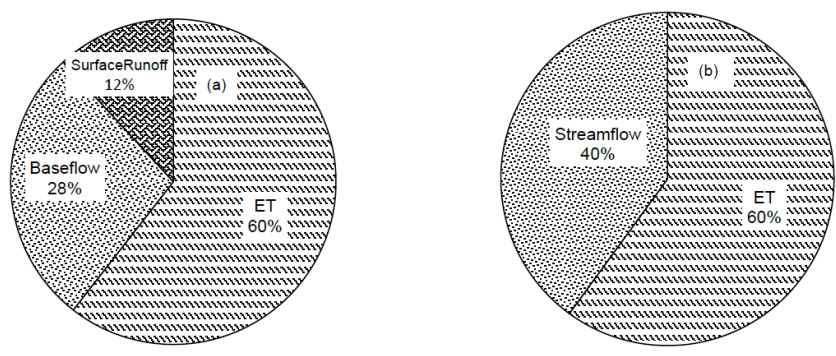

Fig. 5. (a) Observed and (b) CANWET simulated average annual water budget over 10 year period (19901999). seasonal, monthly, and daily time frames, and are presented below.

\section{Annual analysis}

A comparison of observed and CANWET simulated annual streamflow for the period 1990 to 1999 is presented in Fig. 3. A close agreement between the simulated and observed streamflows is evident, with an average annual error of $0.5 \%$. However, the percent error varied from year to year. For relatively wet years (1992-93) the model underestimated streamflow by $20 \%$ whereas for relatively dry years (1998 and 1999) the model overestimated streamflow by $38 \%$. The scatter plot of observed and simulated streamflows (Fig. 4) yielded high correlation; however, the slope of the trend line indicated that the model had a tendency to underestimate high flows and overestimate low flows. This discrepancy could be due to the $\mathrm{CN} 2$ values being extracted based on the general watershed characteristics. The database available for CN2 values represents normal watershed conditions. These values were changed to $\mathrm{CN} 3$ (wet conditions) or CN1 (dry conditions) based upon Antecedent Moisture Conditions (AMC), as needed and according to the time step being used (daily or monthly). However, CN2 values are not changed in CANWET at annual time steps to represent dry or wet years. The prolonged saturated conditions of wet years and the over-drained conditions of dry years have a tendency to produce relatively larger and smaller flows, respectively. The lack of flexibility in $\mathrm{CN} 2$ at annual time step could be the reason that streamflows were under estimated in wet years and overestimated in dry years.

The components of the annual water budget simulated by CANWET were compared to observed data. Annual conceptual ET was computed as the difference between annual precipitation and streamflow. Figure 5 shows a comparison between the simulated and observed components. Based on 10 years of data, CANWET partitioned annual precipitation into $60 \%$ of ET and $40 \%$ of streamflow (28\% baseflow and $12 \%$ surface runoff). These average values match well with the averages of the observed water budget components (Fig. 5). On the other hand, the year-to-year water budget components show considerable variation. Simulated ET varied from $50.5 \%$ to $72.2 \%$, surface runoff from $8.1 \%$ to $15.9 \%$, baseflow from $17.3 \%$ to $38.6 \%$, and streamflow from $27.8 \%$ to $49.5 \%$ of precipitation. The conceptual ET varied between $40.4 \%$ and $79.6 \%$ and observed streamflow varied between $20.4 \%$ and $59.6 \%$ over the simulation period.

\section{Seasonal analysis}

The observed seasonal and CANWET simulated streamflow hydrographs were compared for the ten years period used for model simulation. Simulated seasonal streamflow followed the observed seasonal streamflow trends. The statistical comparison yielded a Nash-E of 0.67 and an $\mathrm{R}^{2}$ of 0.68 , indicating good agreement between observed and simulated seasonal streamflows. For the average seasonal streamflow over the ten-year period the Nash-E and $R^{2}$ were 0.94 and 0.99 , respectively. 


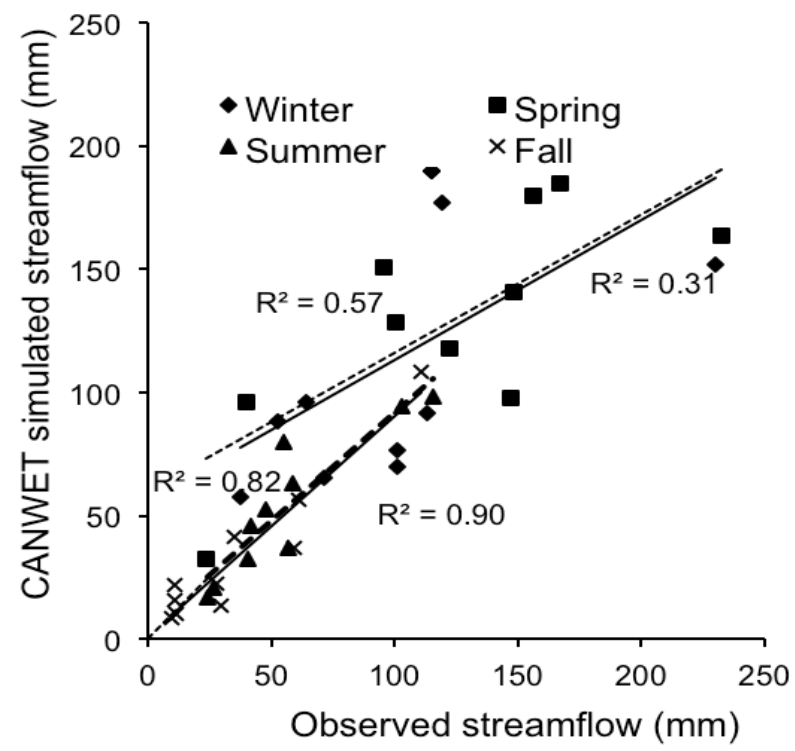

Fig. 6. Scatter plot for seasonal observed and CANWET simulated streamflows.

The observed and CANWET simulated seasonal streamflows were also compared for each season separately over the 10 year period. The streamflow in spring, summer, and fall seasons closely followed the observed streamflow pattern, with Nash-E values of 0.56 , 0.66 , and 0.78 , respectively. However, there was much more discrepancy between observed and simulated streamflows for the winter periods with Nash-E reduced to 0.24 .

Further, the scatter diagram was plotted between observed seasonal and CANWET-simulated streamflows (Fig. 6). It shows similar trends for winter and spring simulations, and for summer and fall simulations. The winter and spring trend lines are flatter compared to the 1:1 line, indicating that the model under-estimated high flows and over-estimated low flows. However, summer and fall trend lines indicated strong correlation between observed and simulated streamflows, showing that the model performance was adequate for low flow conditions. The probable reason for the difference in streamflow in winter and spring is due to the simplified snowmelt routine used in CANWET. The CANWET uses a snowmelt equation based on degree-day equation (Haith 1985):

$$
\mathrm{S}_{\mathrm{M}}=0.45 * \mathrm{~T}_{\mathrm{d}}
$$

where $S_{M}$ is snow melt $(\mathrm{cm})$ and $T_{d}$ is the daily average temperature $\left({ }^{\circ} \mathrm{C}\right)$.

However, on number of days during spring and winter seasons the temperature fluctuates from below to above freezing values. The daily average temperatures taken by the model for these days may be below freezing whereas the actual daily maximum temperatures may be well above freezing or vice-versa, thereby skewing runoff simulations. Moreover, the model also determines whether the

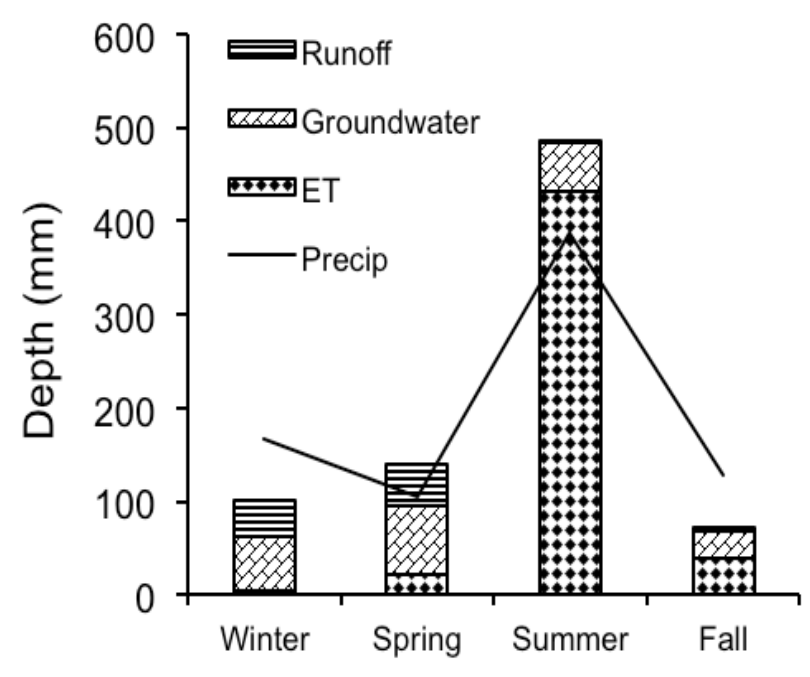

Fig. 7. Average seasonal water budget components for simulation period over 1990-1999

precipitation is rain or snow based on the average temperature. If the average temperature is below zero, all the precipitation is considered to be snow, which may also affect the simulations.

Figure 7 and Table 2 show the results of the seasonal water budget analysis over the ten-year simulation period. It can be seen that the relative contribution of the four water budget component parameters varied considerably from season to season. The ET was highest during summer and constitutes $86.8 \%$ of the total annual ET, but is very low during winter $(0.9 \%)$. However, ET may be underestimated during winter because the model does not account for sublimation. The runoff was highest during spring season $(50.4 \%)$, followed by the winter season $(43.8 \%)$. The frozen and saturated conditions during these months let rainwater and snowmelt flow on the surface. However, runoff was low in summer $(0.4 \%)$ and fall $(5.4 \%)$ because of the dry conditions during these seasons. The surface runoff was somewhat underestimated during summer and fall, which may be due to the fact that only small portion of the watershed, actually contributes surface flow to the stream. Identifying these contributing areas dynamically is still a challenge for hydrologic models, although Beven (2001) has had some success with TOPMODEL.

The baseflow component of the streamflow was consistent in all the seasons with the highest values during spring (34\%) followed by winter and summer. It was lowest during fall $(13.5 \%)$ due to the exhausted unsaturated and saturated sub-surface reserves. The total streamflow peaked during spring season when both surface and baseflow contributions were highest compared to the other seasons. The ET demand was also low in the fall. 


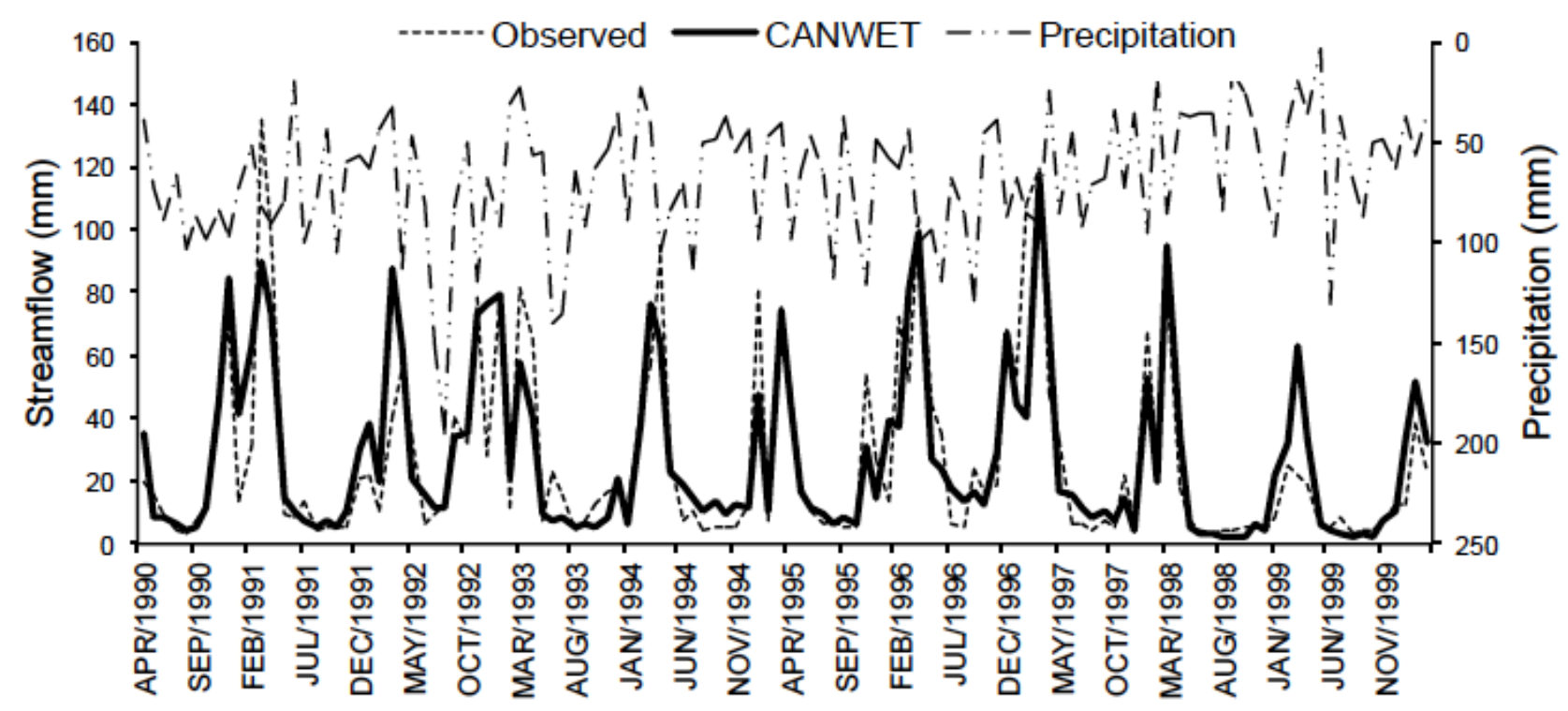

Fig. 8. Comparison of CANWET simulated and observed monthly streamflow

Streamflows were lowest during summer and fall seasons when the ET demand was highest and the water reserves were at lowest level. Moreover, the ET demand was even higher than precipitation in summer and most of the available water (precipitation and soil moisture) was utilized to meet it, thus leaving limited water contributing to the streamflow.

\section{Monthly analysis}

A comparison of the monthly simulated and observed streamflow hydrographs is presented in Fig. 8. It can be seen that the peaks and troughs of simulated hydrographs follow observed trends; however, there were some inconsistencies in the magnitude of the peaks. A statistical comparison of the hydrographs yielded a Nash-E of 0.68 , and $\mathrm{R}^{2}$ of 0.68 , which indicates good performance for the model. Further, the Nash-E and $\mathrm{R}^{2}$ for the average monthly simulated and observed streamflows were estimated to be 0.95 and 0.97 , respectively, which also shows good performance of the model simulations.

Table 2. Seasonal water budget components simulated by CANWET

\begin{tabular}{crrrcc}
\hline Season & \multicolumn{5}{c}{ Water budget parameters (\%) } \\
\cline { 2 - 6 } & $\begin{array}{c}\text { Precipi- } \\
\text { tation }\end{array}$ & ET & $\begin{array}{c}\text { Surface } \\
\text { Runoff }\end{array}$ & baseflow & $\begin{array}{c}\text { Stream } \\
\text { flow }\end{array}$ \\
\hline Winter & 21.2 & 0.9 & 27.1 & 43.8 & 32.0 \\
Spring & 13.3 & 4.6 & 34.0 & 50.4 & 38.9 \\
Summer & 49.1 & 86.8 & 25.4 & 0.4 & 17.9 \\
Fall & 16.4 & 7.7 & 13.5 & 5.4 & 11.1 \\
\hline
\end{tabular}

Winter = December, January, and February;

Spring $=$ March-April;

Summer = May-September;

Fall $=$ October-November
Figure 9 shows a scatter plot for monthly observed and CANWET simulated streamflows. Comparison of monthly scatter plots with annual (Fig. 4) and seasonal (Fig. 6) scatter plots reveal that the scatter further increased; however, the spread was still even along the best-fit line. Further, the trend lines for winter and spring months were flatter compared to the trend lines for the summer and fall months indicating that higher flows are underestimated and lower flows are over estimated in the months falling in winter and spring.

Simulated streamflows for each month were also compared with the observed streamflows. The comparison indicated a good agreement between the simulated and observed streamflows for the months falling in spring, summer, and fall seasons. However, there were incongruities between the streamflows in January and February. The reason for the disagreement was possibly the same as described earlier in the seasonal analysis section, which is due to the simple snow melt estimation approach that CANWET uses.

Comparison of the simulated and observed monthly streamflows was also done using the probability of exceedance of flow over the ten years period and the results are presented in Fig. 10. This indicates good agreement between simulated and observed monthly streamflows for a range of high, medium and low flows.

Figure 11 presents the long-term average monthly water budget for the 10 years period. It shows that the monthly precipitation ranged from $46.3 \mathrm{~mm}$ to $92.0 \mathrm{~mm}$, and it was lowest from February to March and highest from June to August. The monthly averaged ET ranged from $1 \mathrm{~mm}$ to $122 \mathrm{~mm}$. It was lowest during the months of January and February and highest during June. Average monthly surface runoff ranged from almost negligible (May to October) to $44.1 \mathrm{~mm}$ (March). The surface runoff 


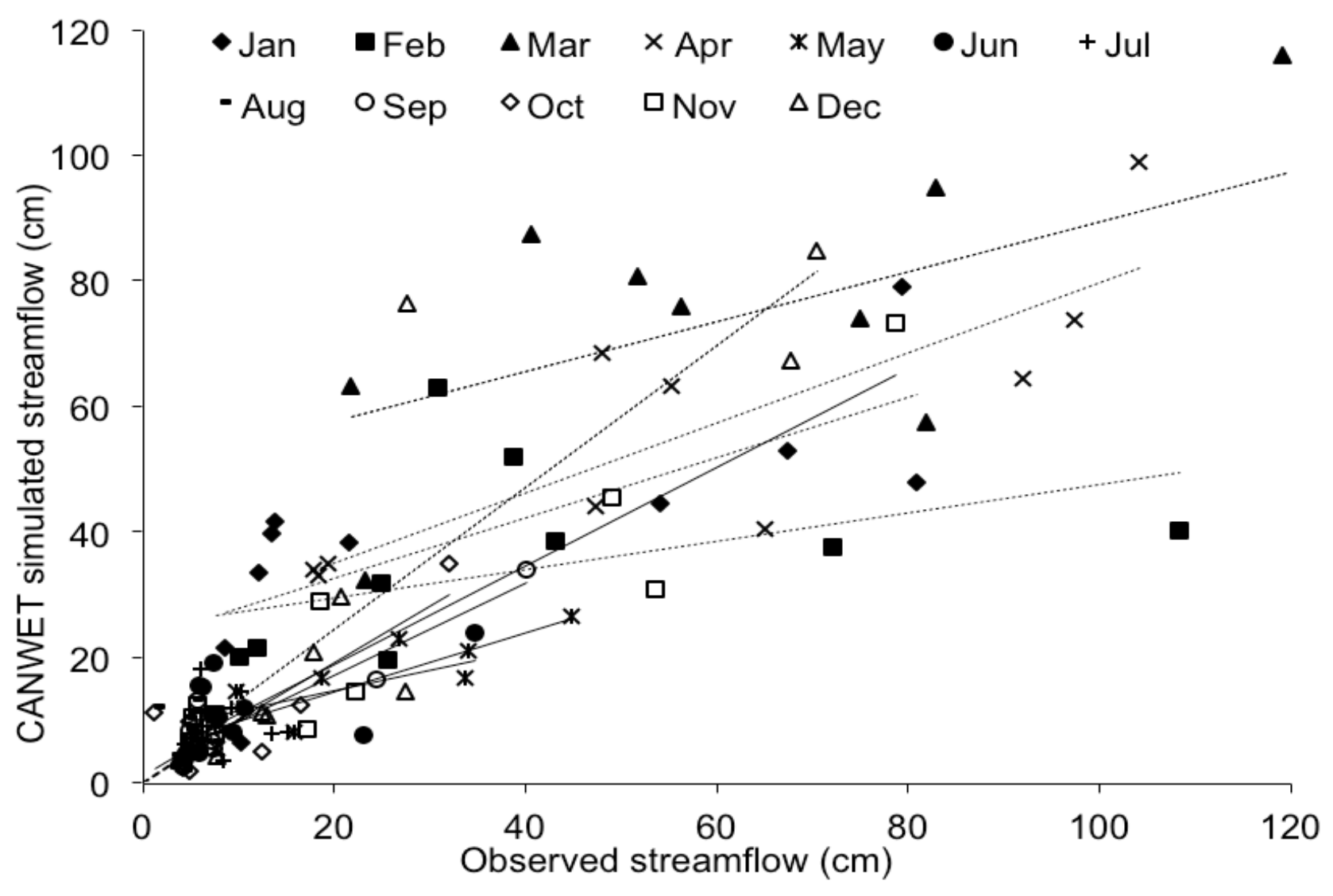

Fig. 9. Scatter plot for monthly observed and simulated streamflow (Dotted trend lines are for winter and spring months and bold for summer and fall months).

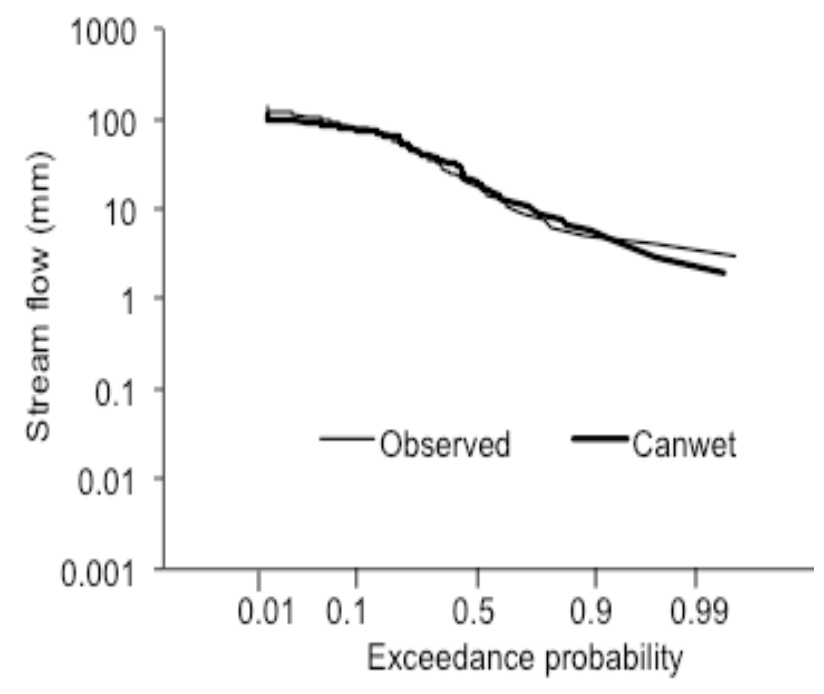

Fig. 10. Probability of exceedance for monthly observed and CANWET simulated streamflow from 1990 - 1999 was low during the summer and fall months (May to October) because the soils were essentially dry during this period and had a larger capacity to hold water. Recent field investigations under simulated rainfall intensities of 100 $\mathrm{mm} / \mathrm{hr}$ have indicated that these soils do not generate any runoff for up to the initial 30 minutes of rainfall (Rudra, Professor, University of Guelph, personal communication). The ET demand is also very high during this period and often exceeds precipitation. Therefore, most of the monthly available water, whether as precipitation or present in the soil, is used to fulfill the ET demand. The baseflow ranged from $6.9 \mathrm{~mm}$ (August) to $49.8 \mathrm{~mm}$ (April). The average streamflow over twelve month period ranged from $72 \mathrm{~mm}$ to $77.2 \mathrm{~mm}$. The streamflow during the months of JuneOctober was primarily the baseflow contribution from the aquifer. This streamflow pattern typically represents the medium textured watershed where the major flow contribution comes from the sub-surface flow.

\section{Daily streamflow analysis}

The daily simulated and observed streamflow hydrographs over 10 year period are presented in Fig. 12. Results show that the simulated hydrograph follows the same pattern as 


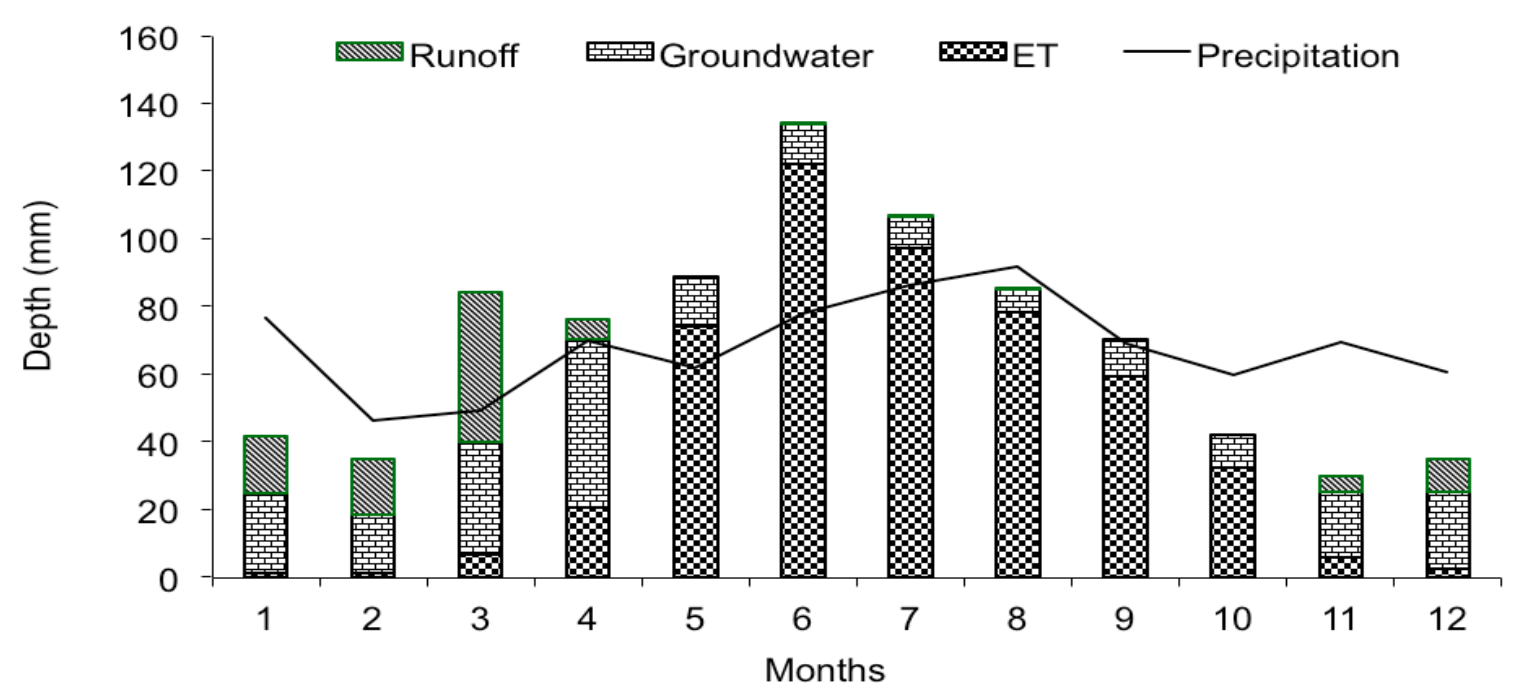

Fig. 11. Monthly average simulated water budgeting of Upper Canagagigue Creek watershed for duration between 1990 and 1999.

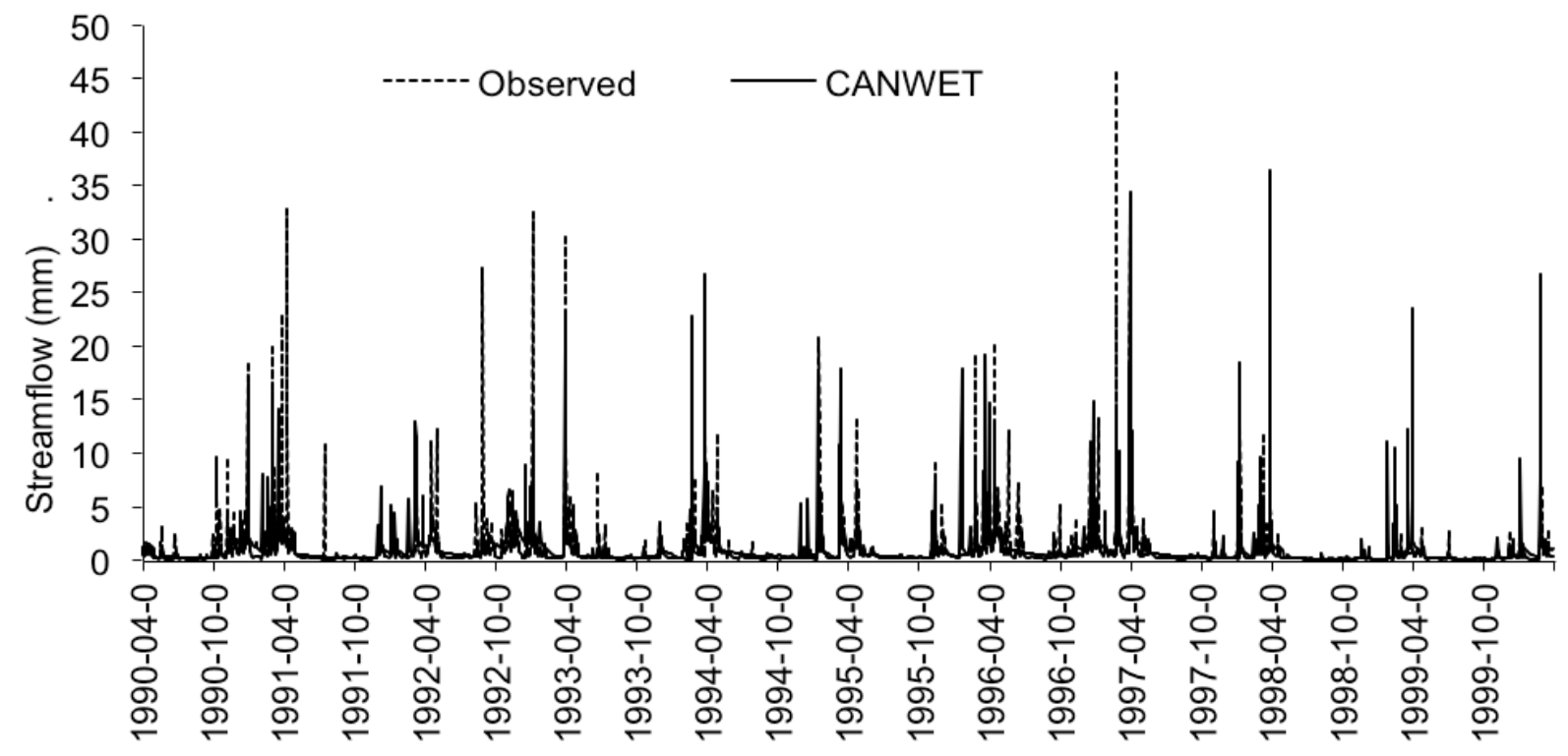

Fig. 12. Observed and CANWET simulated daily streamflow from 1990 - 1999

that of the observed hydrograph; however, there are some inconsistencies in time and magnitude of peaks at some points. The statistical analysis for simulated and observed streamflows yielded a Nash-E of 0.16 and $\mathrm{R}^{2}$ was 0.28 and shows limited correlation, which could be due to the differences in peak flows. Figure 13 reveals that the scatter further increased compared to the scatter for the monthly simulated and observed flows. The trend line also suggests that the model underestimated the high flows; however, the cluster is close to the origin indicated some association between the observed and simulated daily low flows. Further, the probability of exceedance presented in Fig. 14 reveals that the CANWET simulated streamflow probability curve is similar to the observed streamflow probability curve. However, there are some disagreements in flows at certain intermittent levels. In general, there is concurrence between the observed and simulated streamflows. The absence of channel routing component in 


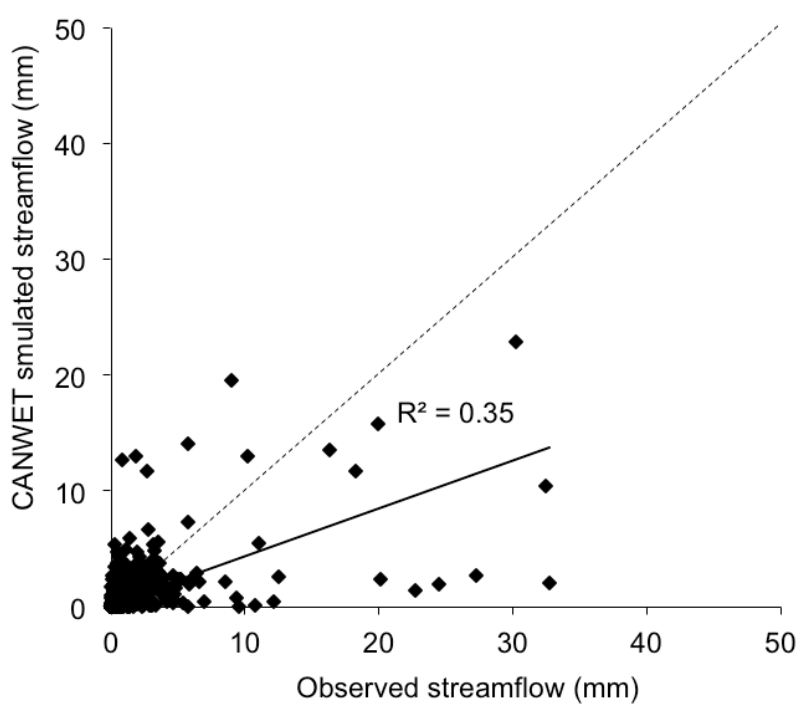

Fig. 13. Scatter plot for daily observed and simulated streamflow

the model could be the possible reason that is resulting in discrepancies between the daily observed and simulated flows.

\section{CONCLUSIONS}

This paper discusses both the advantages and limitations of watersheds-scale hydrologic models for water budget calculations. The use of hydrologic models has been suggested by Ontario Ministry of Environment for water budget estimation due to lack of field data in appropriate spatial and temporal resolution for direct calculation of the main components of the water budget, including evapotranspiration and groundwater recharge on a watershed scale. A variety of watershed models have been listed in the source water protection guidance document, which includes SWAT, GAWSER, HSPF, CANWET etc. The modeling methodologies used in these models vary in procedural complexities and spatial and temporal resolution. In this study the CANWET model, which uses physical though relatively simplified approach, was evaluated for water budget at annual, seasonal, monthly, and daily time-steps. CANWET uses limited parameters for simulating hydrology of a watershed. It considers spatial distribution of land use and soil parameters; however, not the temporal changes in land use during simulation period. Model has capability of changing hydrologic parameters over months to mimic seasonal variations in these parameters.

The CANWET model was applied on Upper Canagagigue Creek watershed. The model simulated and observed stream flows compared well on annual $\left(\mathrm{R}^{2}=\right.$ $0.89)$, seasonal $\left(\mathrm{R}^{2}=0.68\right)$, and monthly $\left(\mathrm{R}^{2}=0.68\right)$ time frames. However, the model did not predict the hydrographs well for the daily flows.

Some of the advantages and disadvantages observed in the CANWET model while applying to the Upper Canagagigue Creek watershed are as follows:

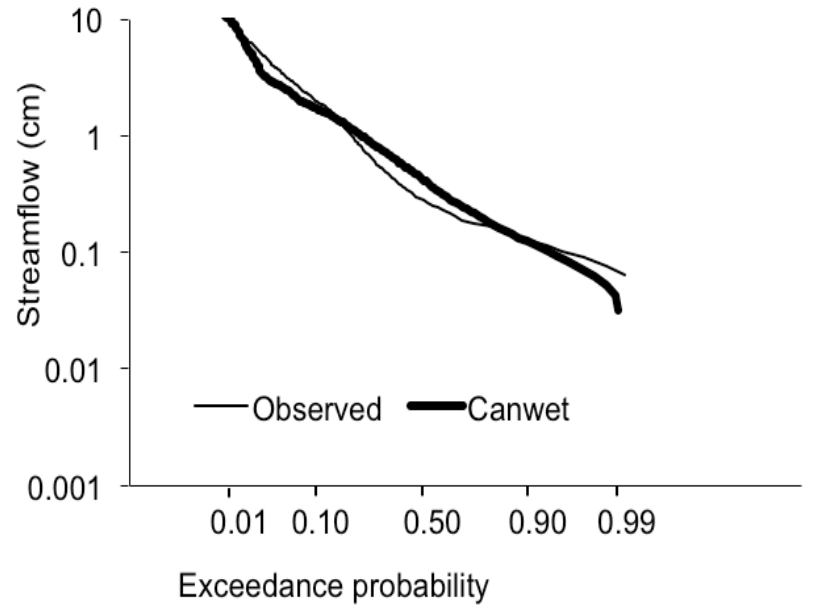

Fig. 14. Probability of exceedance for daily observed and CANWET simulated streamflow from 1990 - 1999

The CANWET model is very simple to use and considers limited parameters for hydrologic simulations at watershed scale. Because the model uses simple algorithms, it is suitable for monthly, seasonal, and annual water budget; however, the simulations at daily time steps are not very promising. The snowmelt algorithm used in the model uses degree-days approach. A more robust approach, which considers snow density and snow compaction, could provide better results during winter and spring months. Recognizing the strengths and weaknesses of the CANWET model it is concluded that CANWET has the potential to address the objective of source water protection stated in the Ontario Clean Water Act, which has its main focus on annual water budgeting.

\section{ACKNOWLEDGEMENT}

The authors are grateful for the financial support provided by Ontario Ministry of Agriculture, Food and Rural Affairs, Greenland International Consulting Ltd., and the Natural Sciences and Engineering Research Counsel of Canada.

\section{REFERENCES}

Al-Abed, N.A. and H.R. Whiteley. 2002. Calibration of the Hydrological Simulation Program Fortran (HSPF) model using automatic calibration and geographical information systems. Hydrological Processes 16(16): 3169-3188.

Arnold, J.G., R. Srinivasan, R.S. Muttiah and J.R. Williams. 1998. Large area hydrologic modeling and assessment Part I: model development. Journal of the American Water Resources Association 34(1): 73-89

Benham, B.L., K.M. Brannan, G. Yogow, R.W. Zeckoski, T.A. Dillaha, S. Mostaghimi and J.W. Wynn. 2005. Development of bacteria and benthic total maximum daily loads: a case study, Linville Creek, Virginia. Journal of Environmental Quality 34(5): 1860-1872. 
Beven, K. J. 2001. Dalton Medal Lecture: How far can we go in distributed hydrological modelling? Hydrology and Earth System Sciences 5(1): 1-12.

Bicknell, B.R., J.C. Imhoff, J.L. Kittle, Jr., T.H. Jobes and A.S. Donigian, Jr. 2001. Hydrological Simulation Program - FORTRAN (HSPF): User's Manual for Version 12.0. Athens, GA: USEPA.

Boston, T., B. Evans, M. Walters and M. Richardson. 2006a. Application of a GIS-Based Nutrient Loading Assimilative Capacity Studies in the Lake Simcoe and Nottawasaga River Basins. In Proceedings HydroInformatics, 2149-2156. Nice, France. September 4-8.

Boston, T., T. Gaul, B. Evans, R. Baldwin, R. EL-Farhan and M. Walters. 2006b. Application of a GIS- Support Assimilative Capacity Studies and Maximum LoadTarget Setting in the Lake Simcoe Basin. In Conference of the Canadian Water Resources Association. Toronto, ON. June 4-7.

Chin, D.A. 2000. Water Resources Engineering. http://books.google.ca/books? sitesec=reviews\&id=Eg hSAAAAMAAJ Upper Saddle River, NJ: Prentice Hall.

Greenland. 2004. CANWET User's Guide. Greenland International Consulting, Collingwood, Canada.

Greenland. 2007. CANWET 3.0. Canadian Nutrient and Water Evaluation Tool Greenland International Consulting, Collingwood, Canada.

Haith, D.A. 1985. An event-based procedure for estimating monthly sediment yields. Transactions of American Society of Agricultural Engineers 28(6): 1916-1920.

Haith, D.A. and L.L. Shoenaker. 1987. Generalized watershed loading functions for stream flow nutrients. Water Resources Bulletin 23: 471-478.

Haith, D.A., R. Mandel, and R.S. Wu. 1992. GWLF: Generalized Watershed Loading Functions, Version 2.0 - User's Manual. Ithaca, NY: Department of Agricultural and Biological Engineering, Cornell University.

Hamon, W.R. 1961. Estimating potential evapotranspiration. Journal of Hydraulic Division 87 (HY3): 107-120.

MOE (Ontario Ministry of Environment). 2006a. News Release by the Ontario Ministry of the Environment. http://www.ene.gov.on.ca/envision/water/cwa.htm $(2009 / 07 / 07)$

MOE (Ontario Ministry of Environment). $2006 \mathrm{~b}$. Assessment Report: Draft Guidance Modules. http://www.ene.gov.on.ca/envision/water/cwaguidance.htm (2009/07/07)
Nash, J.E. and J.V. Sutcliffe. 1970, River flow forecasting through conceptual models part I - A discussion of principles. Journal of Hydrology 10 (3): 282-290.

Schroeter, H. 1996. GAWSER: Guelph All-Weather Sequential-Events Runoff Model - Training Guide and Reference Manual. Guelph, ON: Schroeter and Associates.

ShuKuang, N., N.B. Chang, J. KaiYu and T. YiHsing. 2006. Soil erosion and non-point source pollution impacts assessment with the aid of multi-temporal remote sensing images. Journal of Environmental Management 79(1): 88-101.

Singh A, R. Rudra, S. Ahmed, S. Das, B. Gharabaghi and P. Goel. 2007. Application of CANWET and HSPF for TMDL Evaluation under Southern Ontario Conditions. In Proceedings of Fourth conference on watershed management to meet water quality and TMDLS (TOTAL MAXIMUM DAILY LOAD), 35-42. St. Antonio, TX. March 11-14.

Singh, J., H.V. Knapp, J.G. Arnold and M. Demissie. 2005. Hydrological modeling of the Iqoquois river watershed using HSPF and SWAT. Journal of the American Water Resources Association 41(2): 343360.

USDA-SCS (U.S. Department of Agriculture-Soil Conservation Service), 1972. Hydrology. In National Engineering Handbook, ed. USDA-SCE, Section 4, Chapter 4-10. Washington, D.C.: USDA Soil Conservation Service.

USEPA (U.S. Environmental Protection Agency), 2001. Better Assessment Science Integrating Point and Nonpoint Sources - BASINS Version 3.0, User's Manual. EPA-823-B-01-001, Washington, D.C.: USEPA.

Van Liew, M.W., J.G. Arnold and J.D. Garbrecht. 2003. Hydrologic simulation on agricultural watersheds: choosing between two models. Transaction of American Society of Agricultural Engineers 46(6): 1539-1551.

Watts, S., B. Gharabaghi, R.P. Rudra, M. Palmer, T. Boston, B. Evans and W. Walters. 2005. Evaluation Management Model CANWET in Ontario. In Proceedings of the 58th Annual Conference of the Canadian Alberta. June 14-17 